\title{
How does the circular economy discourse affect policy-making? The case of streamlining waste utilisation in Finnish earthworks
}

\author{
Corresponding author: \\ Erkki-Jussi Antero Nylén, \\ Faculty of Management and Business \\ Tampere University \\ Kanslerinrinne 1 (Pinni A) \\ 33014 TAMPERE, Finland \\ erkki-jussi.nylen@tuni.fi \\ Co-author: \\ Jani Markus Salminen, \\ Centre for Sustainable Consumption and Production \\ Finnish Environment Institute \\ P.O. Box 140, FI-00251 HELSINKI, Finland \\ jani.salminen@ymparisto.fi
}




\section{Abstract}

Since entering the waste policy debate in the 1980s, the sustainability discourse has sought to find alternatives to end-of-pipe solutions. The latest development on this path is the emergence of the circular economy, which aims to close the loop of the current linear economy. This case study analyses a substantial Finnish waste policy reform that has been underway since the late 1990s. The objective of the reform has been to create a decree that streamlines waste utilisation in earthworks. The decree was prepared between 2000 and 2006, and then reformed between 2015 and 2018. We analysed the discursive spaces of both phases and compared them to interpret the changes in the discourse of waste policy. The discursive space in the preparation phase was structured by the tension between the discourses of resource efficiency and precaution, but in the reform, the emergence of the circular economy diversified the discursive space. The thinking regarding the circular economy has added complexity, competition, and struggle to waste policy, but also enhanced the role of upcycling.

Keywords: circular economy, policy formulation, waste utilisation, discursive space, upcycling, deregulation

\section{Graphical Abstract}

\section{CASE STUDY:}

The policy process to draft a decree for facilitating waste utilisation in Finnish earthworks

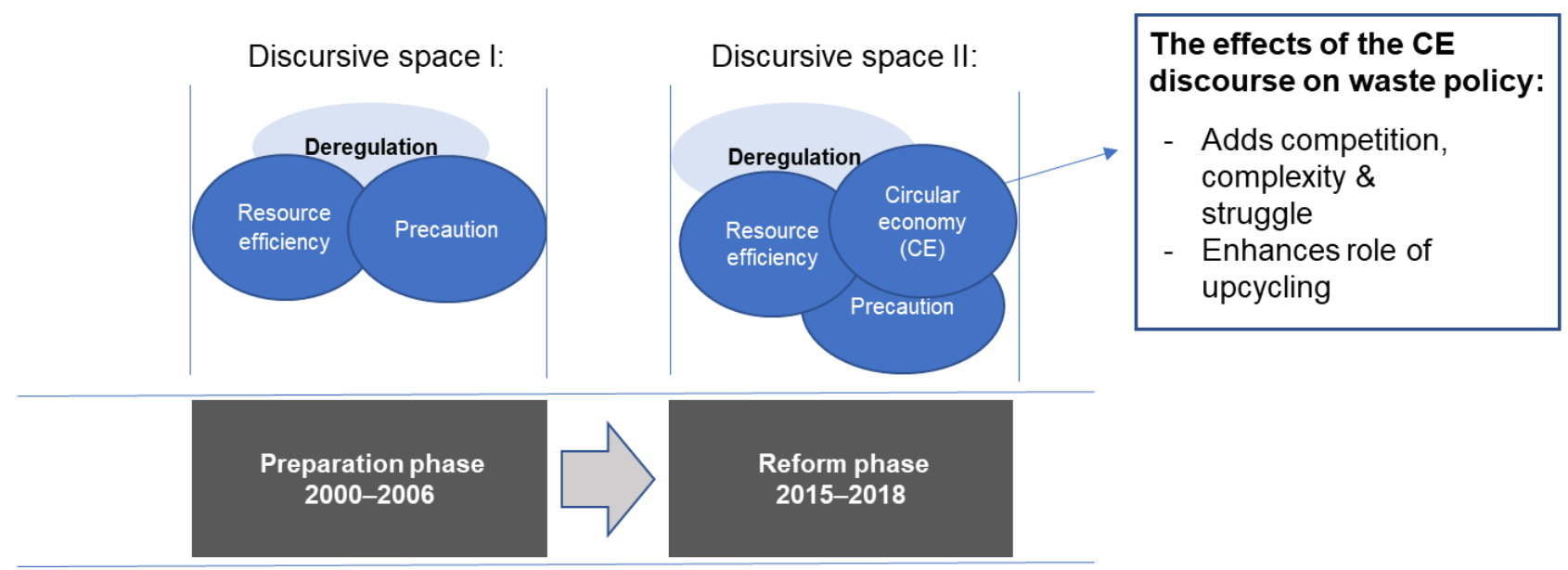

\section{Introduction: The rise of the circular economy discourse in waste policy}

Today, waste policy is a highly regulated field of public policy, especially in industrialised countries. Originally, the guiding principles of waste management were cleanliness and human health concerns, and the tools for meeting those principles were - and generally still are - landfill and incineration. The increase in the coverage of sustainability issues has created pressure to find alternatives to end-of-pipe solutions. As a result, several practices (e.g. recycling, reuse, and waste utilisation) and policies (e.g. waste hierarchy and zero-waste programmes) have risen as new alternatives to manage the demand to reduce waste generation and pursue utility from wastes. On this basis, it seems waste and product policies are increasingly being integrated (Silva, Rosano, Stocker, \& Gorissen, 2017; Silva, Stocker, Mercieca, \& Rosano, 2016; Hultman \& Corvalles, 2012). 
The latest integrative development is the emergence of the circular economy (CE). On a general level, the CE involves a shift away from the linear 'take-make-use-dispose' economy to a more circular one (e.g. Jurgilevich et al., 2015) in which the practices of 'taking' and 'disposing' are small, if not non-existent. CE thinking has gained notable popularity as a result of the promotional work of the Ellen MacArthur Foundation (e.g. Hill, 2015).

Despite the popularity of the $\mathrm{CE}$, scholars have raised various doubts, questioning the concept's capacity to be influential. First, there are numerous definitions of the $C E$, so it can mean different things to different actors (Kirchherr, Reike, \& Hekkert, 2017). Second, the CE is seen as a cluster concept that binds together related sub-concepts (e.g. Nylén, 2019; de Jesus \& Mendonça, 2018). This can be an advantage, but it also means the concept has internal complexities (Korhonen, Nuur, Feldmann, \& Birkie, 2018). Finally, Blomsma and Brennan (2017) have pointed out that there are theoretical complications involved in CE thinking (see also Korhonen, Honkasalo, \& Seppälä, 2018), and if they are not resolved, the concept is in danger of collapse. Despite these doubts, CE thinking has already made its way into contemporary waste and environmental policy discourses (e.g. Lazarevic \& Valve, 2017; McDowall et al., 2017; Silva et al., 2017; Silva et al., 2016) and policy-making (e.g. Sitra, 2016; European Commission, 2015).

According to Meadowcroft and Fiorino (2017), for a policy concept to be successful in its pursuit of change, it needs to be spread and institutionally embedded within the policy sphere. This means that the concept makes its way into becoming an aim in different policy statements, plans, and programmes. So far, analysis of CE policies and policy-making has been kept within its 'own domain': it has been macro-scale (e.g. Su, Heshmati, Geng, \& Yu, 2013; Domenech \& Bahn-Walkowiak, 2017), assessment-orientated (e.g. lacovidou et al., 2017; Elia, Gnoni, \& Tornese, 2017), and focused on policy mixes to further the CE (e.g. Milios, 2018; Wilts, von Gries, \& Bahn-Walkowiak, 2016). To gain a more comprehensive understanding of the abilities of the CE discourse and to identify what enables and inhibits the transition towards the CE, there is a need for an analysis of what CE thinking does in a specific and established policy field. Waste policy in particular is an important field when considering the effects of the CE discourse (e.g. Gregson, Crang, Fuller, \& Holmes, 2015).

The purpose of this paper is to examine whether CE thinking's change-making agenda matters in the most commanding part of waste policy-making: the drafting of waste regulations. We will analyse a major waste policy reform in Finland: the drafting of the Government Decree on the recovery of certain wastes in earth construction (591/2006) - the so-called MARA decree - which streamlines waste utilisation in earthworks under specific conditions. The MARA decree aims to meet waste management sustainability objectives by saving natural virgin materials - which are used intensively in Finland (Ministry of Finance, 2012) - and creating more functional markets for recovered materials in earthworks (Ministry of the Environment, 2016).

The process of drafting the MARA decree has had two phases of policy formulation (Howlett \& Giest, 2013): the preparation phase (2000-2006) and the reform phase (2015-2018). These phases give us a comparative setup to explore how the topics, ideas, and discussion of waste and waste policy have changed. As the CE has gained growing prominence in Finland in recent years (e.g. Sitra, 2015), we especially examine the role of the CE discourse in that change.

This article continues as follows: next, we outline our analytical framework. It consists of a discussion of policy processes in waste policy and our application of discourse analysis where we utilise the concepts of discursive space, collision point, and discourse structuration. Then we discuss our methodology and present the case description. In the analysis and results section, we explore the discursive spaces of the policy 
formulations and analyse how they were structured through the struggles at the collision points. The final section consists of the discussion and conclusions.

\section{Theoretical framework}

\subsection{Policy process and politics of changing waste regulations}

Policy processes are commonly understood to have five stages: agenda-setting, policy formulation, decisionmaking, implementation, and evaluation. However, policy processes are not linear in nature, but rather cyclic and iterative (Jokinen et al., 2016). During policy formulation, a response to the policy issue is created (Howlett \& Giest, 2013). The processes of drafting regulations are a form of policy formulation, and in Finland, different public- and private-sector stakeholders can be engaged in these processes. The degree of engagement differs; some stakeholders are invited to produce content in the preparatory process according to their expertise or the importance of the institution they represent, while others are given the opportunity to voice their opinions on draft legislation. The lawmaker - i.e. the responsible official - is in a key position in the preparatory process. The lawmaker gathers and assesses the importance of the input (e.g. data, research, arguments) in the process and drafts the legislation to the decision-making (Finlex, 2018).

Waste legislation determines the conditions of how wastes are dealt with. Essentially, waste holders are obligated to get their wastes managed (Waste Act 646/2017). This obligation means costs to those who produce and hold wastes, and business to those who manage it (e.g. Reno, 2009). Reformed waste regulations can increase or decrease the waste holder's obligations while creating business opportunities for some and closing them off for others. Reduced regulation attracts waste holders because it makes administrating waste easier and reduces waste management costs. This taps into the debate on deregulation (e.g. Ayres \& Braithwaite, 1992; Collier, 1998; Lidskog, Soneryd, \& Uggla, 2005).

In sustainability and CE thinking, 'the lack of utility' associated with wastes is problematic. One solution is to turn wastes into resources to gain more utility from them, instead of just dealing with them (Kronenberg \& Winkler, 2009; Frosch \& Gallopoulos, 1989). However, gaining utility from wastes is no easy task. It depends on, among other things, environmental suitability, technical properties, material volume, and market demand (Gregson et al., 2015; Sorvari, 2008).

Some waste materials can be a resource for various production processes, which means the same waste material can produce different sorts of utility. In assessing the options, two concepts from the cradle-tocradle model (McDonough \& Braungart, 2008) - upcycling (e.g. Bridgens et al., 2018; Pol, 2010) and its counterpart downcycling (e.g. Di Maria, Eyckmans, \& Van Acker, 2018) - are useful. Upcycling involves increasing the degree of processing, value, or functionality of the materials. Conversely, downcycling does the opposite. In the case of waste utilisation, an upcycling versus downcycling assessment translates to a comparison of the expected outcomes of utilisation. In general, upcycling is an ideal to be pursued, but in practice, some degree of downcycling is unavoidable, since matter and energy dissipate (e.g. GeorgescuRoegen, 1977). Therefore, upcycling can refer to efforts to slow down and resist 'the quality downfall'. In addition, both concepts have latitude, so what is perceived more as upcycling can have variety of interpretations.

\subsection{Discursive space as a tool for analysing regulatory change}


Hajer (1995, p. 44) defines discourse as an 'ensemble of ideas, concepts and categories through which meaning is given to social and physical phenomena, and which is produced and reproduced through an identifiable set of practices'. This definition sets the focus of the discourse analysis on language in use and the institutional context in which the speech act is made. In our case, the institutional context (Schmidt, 2017) and the policy venue (Turnpenny, Jordan, Benson, \& Rayner, 2015; Timmermans \& Scholten, 2006) play a major role. In the regulatory drafting process, the agenda and objectives are set from the start, as are the protocol of the proceedings and - to some degree - the power relations (who is in charge and who is invited to participate). We see this sort of policy process as being akin to the concept of the nodal point (e.g. Howarth \& Stavrakakis, 2000), where discursive elements come together and form an outcome through articulatory practice. We call this outcome a discursive space. It is a set of discourses through which a problem is discussed in a specific context (Hajer, 1995).

The discourses of the discursive space can be in tension or concordance with one another. Moreover, some form of discursive tension is inevitable if the policy-making causes different actors' perceived interests to collide. Tension can exist between discourses or in the ideational content of a single discourse. Each discourse has its own ideational content, logic of communication (Schmidt, 2008), and argumentative rationality (Hajer \& Versteeg, 2005), which dictate what actors can meaningfully state in the policy process (e.g. Feindt \& Oels, 2005).

The discursive space is not a fixed entity; it can change as articulation progresses. To analyse the dynamics of the formation of the discursive space, we utilise the concept of discourse structuration. According Hajer (1995, p. 60), discourse structuration occurs 'if the credibility of actors in a given domain requires them to draw on the ideas, concepts, and categories of a given discourse'. Kauffman et al. (2016) have identified that discursive struggles are substantial and productive for the discourse structuration process.

In the policy-making process, some struggles add to the structuring of the discursive space, while others are more or less irrelevant. We refer to the substantial struggles as collision points. Actors recognise these points as being crucial to their cause and start arguing for or against a specific idea or development in the policy process. Alternatively, actors can recognise a discursive element as a resource to utilise to further their aims. If the discursive space in its current state does not provide the right amount of 'modes of speech' (Hajer, 1995), actors can try to expand or reduce the discursive space or reshape relationships between the discourses through influential argumentation.

Ultimately, the lawmaker decides the outcomes of the policy formulation and drafts a proposal for the decision-making. For the other actors involved, this means their objective is to input their cause into the draft. In addition to plain, content-focused argumentation, actors can try to position themselves and the other actors involved in the policy process. Actors who are involved in the policy process have room to act, but they are far from omnipotent. Consequently, it is important to take into account the whole setup: agency, strategy, practice, and discourse. The setup should be understood as a fluid ensemble that shapes the way the policy process plays out (Paul, 2009).

\section{Methodology}

Our analysis was formed from three components: (1) the peer debriefings of the authors, (2) extensive and diverse data gathering according to a case study orientation (Thomas \& Myers, 2015), and (3) the exploration of discursive spaces and the analysis of discourse structuration. 


\subsection{Authors' peer debriefings}

The second author was involved in the preparatory work of the reform of the decree as a scientific expert. He also observed the progress and the proceedings of the reform process. The first author analysed the policy process from the outside. He conducted the interviews and the discourse analysis. Both authors had a different angle to perceive the research subject, and through various meetings and correspondence, these angles produced a balanced view of the discursive changes in the policy process. This working method can be described as a sort of peer debriefing (Lincoln \& Guba, 1985; Schwartz-Shea, 2015), which strengthens the interpretations of the analysis.

\subsection{Data}

Extensive and versatile data were gathered. The data consist of different types of document material that have different inputs in the analysis (Table 1). In addition, twelve semi-structured interviews were conducted with actors who participated in the decree's preparation and/or reform process (Table 2). The interviewees were chosen based on their role in the policy process. They provided more insightful descriptions of the proceedings of the policy process.

From the stakeholders who participated and were influential in the policy formulation phases, we identified the following types of actor role: (1) Waste producers, who create the waste and are obligated to have their wastes managed. Waste producers might have sustainability objectives for waste management, but wastes are still a cost burden to them. Therefore, it is in the interest of waste producers to dispose of their wastes easily and at a low cost. (2) Waste processors, who do business in waste materials; some of them process waste further than others do. (3) Waste utilisers, who are usually public actors utilising recovered materials to execute a strategy, like a commitment to use a certain amount of recovered materials in earth construction projects (e.g. Finnish Transport Agency, 2015). (4) Regulators, who aim to guarantee a sufficient level of environmental protection and keep recovery markets viable through policy-making or supervision.

(5) Scientific experts, who provide their expertise in situations where the criteria for utilisation are generated. They are also capable of evaluating the approaches used in setting the quality criteria. (6) Consultants, who represent their customers. They can produce data for the policy process, but they can also represent other types of actor.

Table 1. Types, numbers, and roles of the document material used in the analysis.

\begin{tabular}{|l|l|l|l|}
\hline $\begin{array}{l}\text { Document } \\
\text { type }\end{array}$ & $\begin{array}{l}\text { Number of } \\
\text { documents }\end{array}$ & Name and/or reference & Role of the data in the analysis \\
\hline $\begin{array}{l}\text { Legal } \\
\text { documents }\end{array}$ & 4 & $\begin{array}{l}\text { The original and reformed } \\
\text { decree and their explanatory } \\
\text { memoranda }(591 / 2006, \\
843 / 2017 \text { \& Ministry of the } \\
\text { Environment, 2006; 2017) }\end{array}$ & $\begin{array}{l}\text { Presents the evolution of the official } \\
\text { reasoning for the decree. }\end{array}$ \\
\hline $\begin{array}{l}\text { Draft versions } \\
\text { of legal } \\
\text { documents }\end{array}$ & 2 & $\begin{array}{l}\text { Draft version of the } \\
\text { reformed decree and its } \\
\text { explanatory memorandum } \\
\text { (Ministry of the } \\
\text { Environment, 2016) }\end{array}$ & $\begin{array}{l}\text { Stakeholders were asked to give an opinion } \\
\text { on the drafts. Documents were important } \\
\text { in the reform phase, as they tested the } \\
\text { official reasoning of the reform with the } \\
\text { stakeholders. }\end{array}$ \\
\hline $\begin{array}{l}\text { Background } \\
\text { documents }\end{array}$ & 2 & Mikkola, 2013; VTT, 2006 & $\begin{array}{l}\text { These two documents were chosen due to } \\
\text { their importance in shaping the policy }\end{array}$ \\
\hline
\end{tabular}




\begin{tabular}{|c|c|c|c|}
\hline & & & $\begin{array}{l}\text { formulations: VTT (2006) in the preparation } \\
\text { phase and Mikkola (2013) in the reform } \\
\text { phase. }\end{array}$ \\
\hline $\begin{array}{l}\text { Research } \\
\text { publications }\end{array}$ & 1 & Sorvari, 2008 & $\begin{array}{l}\text { Sorvari (2008) analysed the agenda-setting } \\
\text { and preparation phase of the decree. }\end{array}$ \\
\hline $\begin{array}{l}\text { Stakeholder } \\
\text { opinions on } \\
\text { the draft of } \\
\text { the reformed } \\
\text { decree }\end{array}$ & 67 & $\begin{array}{l}\text { Obtained from the Ministry } \\
\text { of the Environment. } \\
\text { Reference to more than one } \\
\text { opinion in the analysis: } \\
\text { Opinions } 2016 .\end{array}$ & $\begin{array}{l}\text { To reveal the conflicts of interest between } \\
\text { different actors. Actors were grouped } \\
\text { according to their roles, which they } \\
\text { represented during reform process: Waste } \\
\text { producers ( } n=15) \text {, Waste processors ( } n=14) \text {, } \\
\text { Waste utilisers }(n=11) \text {, Regulators }(n=17) \text {, } \\
\text { Scientific experts }(n=6) \text {, Consultants }(n=2) \text {, } \\
\text { an environmental NGO, and a private } \\
\text { individual. }\end{array}$ \\
\hline $\begin{array}{l}\text { Summary } \\
\text { document of } \\
\text { stakeholder } \\
\text { opinions on } \\
\text { the draft of } \\
\text { the decree }\end{array}$ & 1 & $\begin{array}{l}\text { Obtained from the Technical } \\
\text { Research Centre of Finland } \\
\text { (VTT). Reference in analysis: } \\
\text { Opinions } 2005 .\end{array}$ & $\begin{array}{l}\text { The document gives an overview of the } \\
\text { stakeholder opinions given during the } \\
\text { preparation phase in 2005. This document } \\
\text { represents the third round; the other two } \\
\text { rounds are included in Sorvari, 2008. Actor } \\
\text { roles: Waste producers ( } n=6), \text { Waste } \\
\text { processors }(n=3), \text { Waste utilisers ( } n=4) \text {, } \\
\text { Regulators, }(n=10), \text { Scientific experts }(n=3) \text {, } \\
\text { an environmental NGO, and a consultant. }\end{array}$ \\
\hline
\end{tabular}

Table 2. Interviewed actors and their reference codes in the analysis section.

\begin{tabular}{|l|l|l|}
\hline Role of the interviewee & $\begin{array}{l}\text { Number of } \\
\text { interviews }\end{array}$ & Detailed description and reference codes in brackets \\
\hline Regulators & 3 & $\begin{array}{l}\text { Two civil servants from the Ministry of the Environment (Reg1 } \\
\text { \& Reg2) and one from the regional authority that handles } \\
\text { MARA notifications (Reg3). }\end{array}$ \\
\hline Waste producers & 2 & $\begin{array}{l}\text { Two representatives from interest groups who represent } \\
\text { industries producing the wastes included in the decree (Produ1 } \\
\text { \& Produ2). }\end{array}$ \\
\hline Waste processors & 2 & $\begin{array}{l}\text { Two representatives from firms that process the wastes } \\
\text { included in the decree (Proces1 \& Proces2). }\end{array}$ \\
\hline Waste utilisers & 2 & $\begin{array}{l}\text { One interviewee representing a large Finnish city (Uti1) and } \\
\text { another representing a public procurer (Uti2). }\end{array}$ \\
\hline Consultant & 1 & $\begin{array}{l}\text { Produced data for the policy process, but also helped other } \\
\text { types of actor in drafting opinions (Con1). }\end{array}$ \\
\hline Scientific experts & 2 & $\begin{array}{l}\text { Both experts participated in the process during the } \\
\text { preparation phase (Scien1 \& Scien2). }\end{array}$ \\
\hline
\end{tabular}

${ }^{1}$ The second author participated in the reform phase as a scientific expert.

\subsection{Exploration of discursive space and analysis of discourse structuration}

The analysis began with the different decree texts and related drafts, background documents, and a scientific publication (Table 1), from which a preliminary interpretation of discursive spaces was extracted. Three interviews (two with regulators and one with a scientific expert) were conducted and the stakeholder 
opinions were content analysed and grouped according to the actor roles the stakeholders represented in reform process. Finally, an overview document of the opinions on the preparatory phase (obtained from VTT) was analysed, and the rest of the interviews were conducted to perform the final analysis of discursive spaces.

The discourse analysis was an iterative process with two perspectives. First, the limits and the setup of discursive spaces were constantly explored throughout the process. Collision points were identified from the data according how key actors saw the subject matter for their cause and how strongly it was argued upon by the participants. Second, the arguments at the collision points were analysed from the perspective of whether they shaped the decree's outcome after the preparation and reform phases. The concept of discourse structuration was used to analyse the argumentation from the perspective of the type of discursive element used in the argumentation.

\section{The case: The policy process of the MARA decree}

The developments of the policy process to draft the MARA decree are illustrated in Figure 1. Our case study was limited to analysing the policy formulation phases.
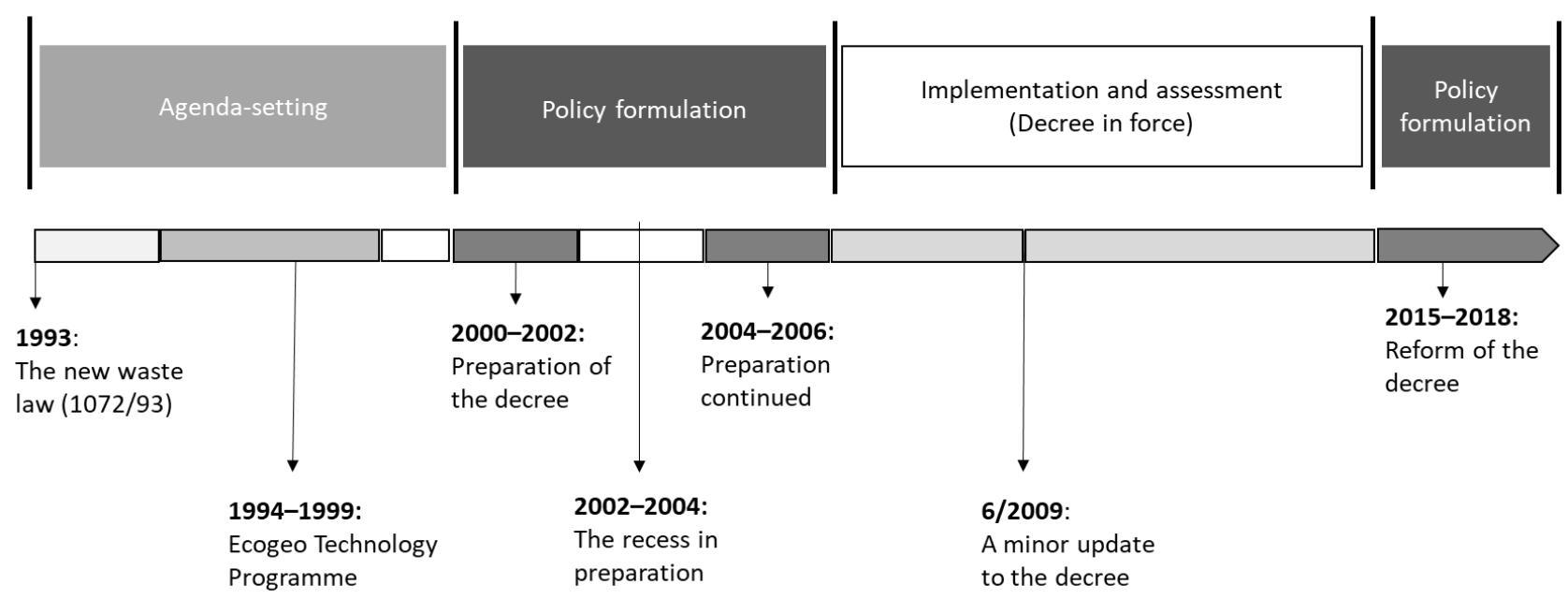

Figure 1. In the timeline ${ }_{2}$ we identified the stages of the policy process in the drafting of the MARA decree.

The new Waste Act (1072/93) started the agenda-setting of the decree. The Act introduced sustainable thinking more forcefully into waste policy and made waste utilisation one of its objectives. In 1995, the socalled Ecogeo Technology Programme was initiated. It developed the scientific basis of waste utilisation in earthworks. At the time, an environmental permit was required for waste utilisation, which slowed and complicated utilisation. Consequently, some industries (metal, energy, forest, and waste processing) lobbied for the administrative practices of waste utilisation to be streamlined, but the original idea of the MARA decree came from the Ministry of the Environment (MoE) (Sorvari, 2008; Scie1; Scie2).

In 2000, a working group was set up at the Finnish Environmental Institute (SYKE) to prepare the decree. The objectives of the decree were to unify waste utilisation practices, create solid scientific criteria for the unification, and promote waste utilisation in earthworks. In 2002, after two years of preparation, the process went into a two-year recess. The Technical Research Centre of Finland (VTT) continued the preparation in 2004. Finally, the MARA decree came into force in 2006 (Sorvari, 2008; VTT, 2006). 
The MARA decree enabled crushed concrete and fly and bottom ash from the combustion of coal, peat, and wood to be utilised through a notification procedure in certain road, street, route, and field structures (Government Decree 591/2006). The decree limited the thickness of the waste material layer and set limit values for the concentrations of various harmful substances in the waste materials (Ministry of the Environment, 2006). In 2009, the decree (403/2009) was updated, when fluidised bed ash was included, and some limit values were slightly adjusted.

Based on an assessment of the decree's effects (Mikkola, 2013), the MoE decided that a reform of the decree was needed. The status of the reform process was elevated when it was chosen as one of the circular economy top projects of Prime Minister Sipilä's government (2015-2019) (Ministry of the Environment, 2017). The reform was conducted in 2015-2018. It added six new waste types (treated slag from waste combustion, crushed bricks, asphalt chippings, foundry sand, lime, and shredded and whole tyres) and new utilisation site types to the decree. In addition, the basis of the limit values for harmful substances was changed from being waste material-specific to utilisation structure-specific. The reform also included limitations. For instance, bottom slag and crushed concrete were prohibited from use in embankments. Instead, these waste materials were to be channelled for 'higher quality' utilisation (Ministry of the Environment, 2016; 2017).

\section{Analysis and results}

\subsection{Changes in the discursive space}

We begin our analysis by presenting the general results. The first result is the setup of the changes in the discursive space between the preparation (2000-2006) and reform (2015-2018) phases (Figure 2) and the effective ideational content of each discourse that generated a discursive space. Figure 2 also illustrates the second set of results, namely the collision points where the key struggles were situated. In sections 5.2, 5.3, and 5.4, we analyse how the actors' argumentation at each collision point structured the discursive spaces of the policy process. The third result is the actor types, which we presented in Section 3.2.

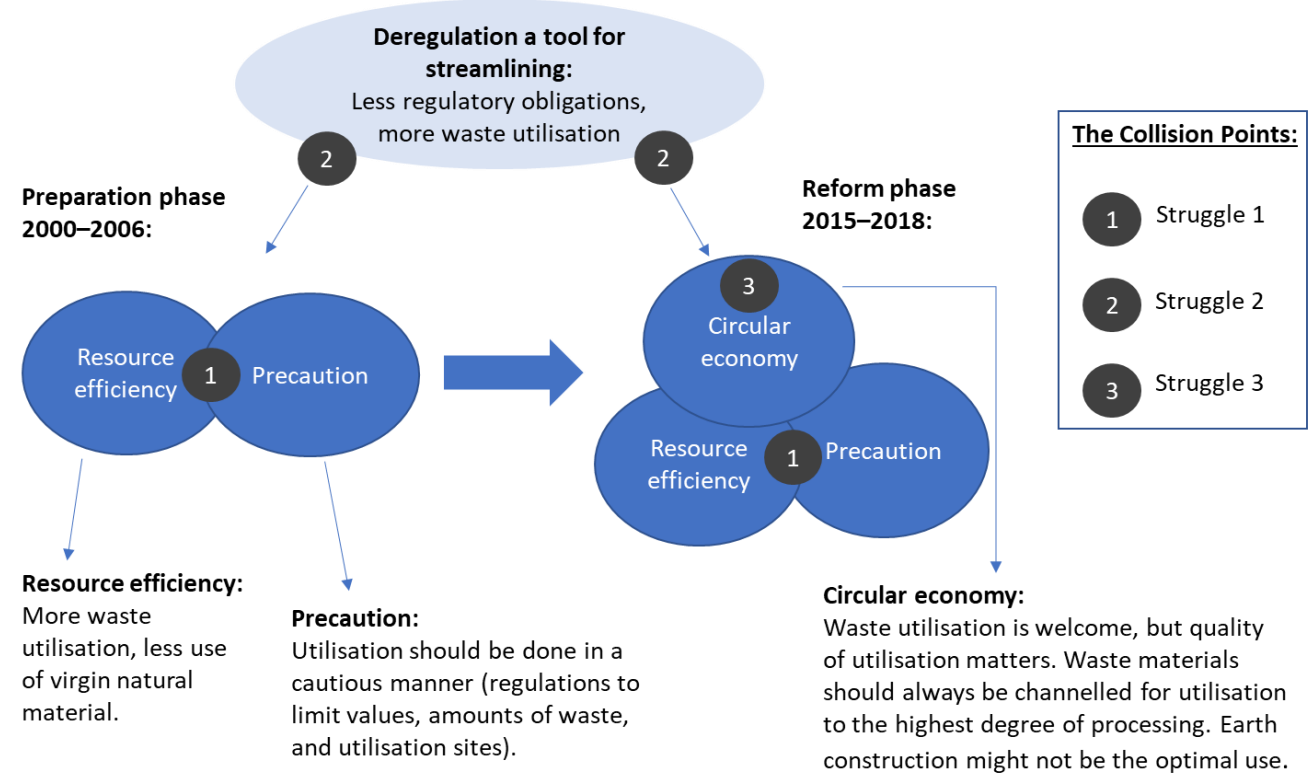


Figure 2. Illustration of the changes in the discursive space from the preparation phase to the reform phase. The illustration also depicts the collision points. Struggle 1: The struggle over limitations; Struggle 2: Facilitation without compromising; Struggle 3: Interpretations of the CE

The policy formulation stages had different discursive space setups, and the relationship between the discourses was different. In the preparation phase (2000-2006), the discursive space was structured by two normative aims, which we name the discourses of resource efficiency and precaution. These aims pull in opposite directions, as resource efficiency tries to increase the reach of the MARA decree while precaution aims to limit it. The aim of resource efficiency lies in utilising more waste types for earthworks, thus saving virgin natural materials. The other aim, precaution, concerns the protection of groundwater and soil from pollution, which is an issue in waste utilisation for earthworks. In other words, precaution acts as a gatekeeper for waste utilisation. This struggle between resource efficiency and precaution also translates into a struggle over deregulation, where the issue of contention is how and to what extent certain practices should be regulated. Here, the discourse of deregulation suggests that fewer regulatory obligations generate more utility, since waste utilisation practices would be eased.

The emergence of the CE discourse diversified the discursive space in the reform phase (2015-2018) compared to the preparation phase. The CE discourse's ideational content (Figure 2) clearly enhanced the discourse of resource efficiency, but waste utilisation itself is not enough for the $C E$, as the quality of utilisation matters as well. The CE discourse assesses quality by asking whether the utilisation of waste materials works in a downcycling or upcycling manner.

\subsection{Collision point I: The struggle over limitations}

The struggle over limitations has been the main issue during the whole policy process because it defines the reach of decree. Tension between the discourses of resource efficiency and precautions provided the actors with discursive elements to use in argumentation. The key issues in this struggle were which type wastes and - to a lesser extent - utilisation sites should be added to the decree, and where the limits of the environmental criteria should be drawn. Every time the decree has been drafted, it has become more permissive. At this collision point, the argument was mostly between scientific experts who did the preparation work and the other parties (excluding the lawmakers, who acted more like referees). The most vocal critics were the waste producers, because the decree would mean the facilitation of their waste management and reduced costs. From the discourse structuration perspective, actors utilised scientific data and knowledge to argue upon the technical and environmental suitability of the waste types.

The struggle over which waste types should be included in the decree was most heated during the preparation phase (2000-2006). The first working group (2000-2002) started the preparation with 21 waste types. However, the working group's scientific expert deemed the data provided by the waste producers to be unreliable in terms of the properties of waste materials and their potential environmental impacts. Consequently, only seven waste types remained in the preparation. The stakeholders (industries who produce or process wastes, authorities, constructors, consultants, and research institutes) were unhappy and voiced their displeasure officially when they were asked to comment on the first draft of the decree (July 2001). They criticised the scope of the decree as being too narrow and wanted more waste types included (Sorvari, 2008, pp. 492-493, 496-498; Scie1). The waste producers in particular claimed there was enough reliable data for more waste types to be included (Scie1). 
The controversial opinions were one of the reasons why the preparation went into a two-year recess (20022004), but the more immediate reasons were other reforms to waste and environmental legislation (Sorvari, 2008; Scie1; Reg1). The MoE directed VTT to continue preparation of the decree (2004-2006). Finally, the decree (591/2006) came in force. According to the opinions (2005) given on the draft, the reach of the decree still displeased the waste producers, processors, and utilisers. They wanted more waste types (crushed brick, glass cullet, asphalt chippings, co-incineration ashes, clean landmasses, and bedrock soils and fibre clays) and utilisation sites (private roads, embankments, and seaport construction applications) to be added to the decree. VTT and the MoE responded by stating that experiences of using the decree would be needed before its reach could be expanded; other waste types could be included in the future once their suitability had been proven. VTT (2006, pp. 4-9) outlined a procedure for this in the decree's background memorandum: the waste producer would need to submit a report to the MoE that proves in detail the waste type's suitability for inclusion in the decree, and this report would be assessed by an independent scientific expert.

During the reform phase (2015-2018), the scope of the decree was no longer criticised for being too narrow. Instead, one waste processor company wanted a more detailed assessment of the environmental suitability of foundry sands and limes, and two regional regulators wanted to exclude treated slag from waste combustion (TSWC) by appealing to a lack of data (Opinions 2017; Proces1). In fact, TSWC is an example how a new waste type was added to the decree. First, TSWC was suggested to the MoE for addition under the decree, and it was considered in the negotiations. In the first meetings, some regulators were against adding TSWC, but those sentiments changed when a representative provided evidence (laboratory and test field studies) of its technical and environmental suitability (Proces1; Sormunen, 2017).

The basis of the environmental criteria applied in the decree has changed over time, but arguments about it remained heated throughout the policy process. The first working group's limit values were based on soil protection, which was largely pioneering work and therefore vulnerable to criticism, like alternative calculations. Basically, the calculations lacked the backing of large masses of accumulated knowledge and experience of use (Reg1; Scie1; Scie2). There was more backing in the second part of the preparation (20042006), as VTT applied the EU-based risk assessment model (VTT, 2006; Reg1; Scie2). During the reform (2015-2018), experts from SYKE changed the base limit values for harmful substances from being waste material-specific to utilisation structure-specific. Simultaneously, the reform took the greatest leap in increasing utilisation, which did not go without criticism from some other scientific experts (Opinions 2017). VTT offered the strongest criticism, as they disapproved of the relaxed environmental criteria, fearing this would bring low-quality recovered materials onto the market. VTT argued that this would harm the recovered materials market and the development of new products.

A significant part of the struggle over limit values dealt with ash wastes. This struggle typifies the front lines between scientific experts, lawmakers, and waste producers. Ash wastes were troublesome because they contain a number of critical contaminants and there were inconsistent data about their technical suitability, but 'due to their considerable volume and lack of recycling options, they were considered as important to include in the decree' (Sorvari, 2008, p. 493). Throughout the policy process, two powerful waste producers, the energy and forest industries, lobbied for laxer limit values by arguing that ash waste utilisation through the notification procedure would be small, while the utilisation potential of ash wastes is great. They backed their argumentation with scientific reports they had commissioned (Opinions 2005; 2016; Produ1; Produ2). The scientific experts felt the lobbying was problematic, as they saw their job was to provide environmental criteria according the scientific model of their choice (Scie1; Scie2; Con1; Opinions 2005). They turned to the lawmaker and stated it would be a political decision if different risk levels were seen to be suitable. The lawmaker acted like a referee and asked the scientific experts to adjust the limit values without elevating the 
risk level too greatly. The scientific experts did so in each phase. In the reform phase, this adjustment was termed 'decision analysis' (Reg1; Reg2).

\subsection{Collision point II: Facilitation without compromising}

The discourse structuration at this collision point concerned the various pressures on the lawmakers to deliver a quality decree. First, lawmakers had the principal responsibility to hold the drafting work together and get the decree done. Second, they had to make the decree's notification procedure as functional as possible for the users and the authorities handling the notifications. Finally, criteria imposed in the decree had to be appropriate, thus increasing the amount of waste utilisation in earthworks without facilitating the utilisation of 'unfit' waste materials.

The drafting of the decree involved a networking process where the various and contradicting interests of actors were present (see Section 3.2). All who participated to the process agreed on a common goal: more waste material should be utilised on the basis of a rigorous scientific model. In the preparation phase, only the environmental NGO disapproved - futilely - of the whole idea of promoting waste utilisation (Opinions 2005), but it changed its view in the reform phase (Opinion 2017).

One of the reasons for the preparation phase dragging on was the dispute over of the scope of the decree. In the reform phase, the process was one of the top projects of the Sipilä government, and this added pressure to ensure an improved decree as an outcome (Ministry of the Environment, 2017). Before the reform process, various waste producers had contacted the MoE to express their desire for a reform to the decree. The MoE commissioned an assessment of the decree, which showed the processing times for the notification procedure were much shorter compared to the environmental permit procedure. Nevertheless, the amounts recovered through the MARA procedure were small. In 2010, recovery constituted $0.7 \%$ of the uptake of virgin gravel and rock materials (Mikkola, 2013). Initially, the plan was to slightly reform the decree, but according the assessment made by scientific experts from SYKE, little could be done with the model applied in the original MARA decree. Therefore, the MoE made the decision that a thorough reform was needed to the basis of the environmental criteria, and this was done by SYKE (Reg1).

When information about plans to reform the decree spread, it generated a great deal of interest. Suggestions for additional waste materials poured in, including 'unfit' ones like manure. Clearly, some waste producers saw the MARA decree as a means of disposing of their wastes easily, which was frustrating for lawmakers (Reg2): 'Occasionally stakeholder opinions left a feeling whatever [waste material and limit value] should pass and it frustrated me a bit because this is not a waste dumping decree'.

Regulators had some reservations about 'the streamlining regulations' discourse. The MARA decree has been seen as one of the success stories of streamlining. In that regard, some feared that the terms and conditions that make the MARA procedure possible have not received enough recognition (Reg2). In addition, it was seen as challenging to create a procedure that would really aid facilitation, as the decree per se does not create demand for waste material utilisation in earthworks. One of the regulators wanted the proper documentation of sites where the MARA procedure has been used, which has been missing so far (Reg1). Finally, the notification procedure was an on/off type of instrument where ideally there should be no need for interpretation during the approval procedure. However, in reality, there was regional variance in what type of MARA notifications were accepted before the reform (Reg3; Produ1; Produ2; Proces2).

Consequently, reforming the decree felt like a tightrope walk for the lawmakers, who were responsible for getting the balance right between resource efficiency, precautions, facilitation, and the promotion of the CE. 
For the lawmaker, the biggest risk was that streamlining might enable the use of 'unfit' materials in earth construction, thus tarnishing the reputation of recovered materials. Wastes already have a negative image: when people hear the word 'waste', clean crushed concrete is not the first to spring to mind (all interviews).

\subsection{Collision point III: Interpretations of the CE}

At the same time the reform of the MARA decree (2015-2018) was in motion, CE thinking started to gain topicality in Finland (e.g. Sitra, 2015), and it made its way into the strategies of various actors. An authoritative example is the Finnish Transport Agency (2015): the agency supports the CE and aims to utilise more waste and recovered materials in road construction. The discourse of the CE was utilised in the argumentation of the reform process, and it made changes to the reach of decree.

Stakeholders recognised the argumentative power of the concept of the CE, and when it suited, the CE was used as an argument to justify the stakeholders' take on the reformed draft decree (Opinions 2017). The division in the opinions was clear. Those who sought to benefit from the streamlining saw the decree as a way to apply CE thinking in practice. Others, who were interested in processing wastes further, thought the MARA decree was not ambitious enough in terms of CE thinking. For example, one waste processor company argued that the reformed decree could erode the viability and development of waste utilisation methods that are more upcycling-focused. Therefore, the company wanted more restrictive limits and the implementation of a strictly interpreted waste hierarchy.

During the reform process, the discourse of the CE affected the reach of the decree, as various waste processors imposed the idea on the lawmakers that waste utilisation can be perceived of hierarchically (Proces1; Proces2; Reg1; Reg2). From that view, earthworks represent bulk-form (downcycling) waste recovery, at least when compared to utilising ash waste as fertiliser, recycling asphalt chippings in the asphalt production process, or recycling crushed concrete in the concrete production process. These types of upcycling-focused methods are under development and/or trying to enter the market.

As a result, the reformed decree sets restrictions on utilising particular waste types in particular structures in order to create incentives to channel those wastes into more upcycled uses than earth construction (Ministry of the Environment, 2016; 2017). Waste producers, some processors (demolition contractors), and some utilisers criticised the restrictions. In particular, the waste utilisers criticism was authoritative because waste utilisation in earthworks is clearly more integrated with waste policy than it is with construction policy:

It goes like, 'We have this waste and we need to get rid of it'. Not like, 'We have this construction project. Where could we find suitable waste material to replace crushed rock material?' (Reg3)

The priorities for waste utilisers are the technical suitability of earth construction material and costs, and if the waste materials meet these requirements, they can be considered. Thus, utilisers claimed restrictions complicated utilisation because it was already hard enough to find suitable utilisation sites (Uti1; Uti2; Opinions 2017).

The idea of upcycling was one of the guiding principles of the decree's reform:

Interviewer: Why was the original decree wanted? What was the demand for it? Reg1: We wanted to make the utilisation of waste more flexible in an environmentally friendly way. The agenda is still the same today. Probably the new nuance has become that the first 
top priority is waste utilisation combined with environmental protection. Now, a principle has been added that the decree must not prevent CE innovations or waste processing.

The above quotation indicates there were two ideas about how waste utilisation should evolve after the renewal of the MARA decree. First, there should be more opportunities for waste utilisation. Second, a more upcycling type of utilisation is better. These two guiding principles conflict with each other: the MARA procedure could enable the consumption of waste materials that might be used in more upcycling methods, removing the incentive to develop those methods. This posed a problem for the lawmaker: how could one write regulations that facilitate more waste utilisation, but at the same time avoid preventing CE innovations or waste processing? The clearest option to resolve the potential conflict is to make the decree stricter if the need arises (Reg1). Ideally, the market mechanism would solve the dilemma and the highest bidder would get the waste material, but business currently revolves around avoiding costs and hitting sustainability targets (all interviews).

\section{Discussion and conclusions}

In this paper, we explored how the ideas and aims of waste policy have changed from the early 2000s to the late 2010s by using a decree on waste recovery as an example. We analysed how the discursive space changed between two policy formulation phases - the preparation phase (2000-2006) and the reform phase (2015-2018) - of the policy process for drafting the MARA decree, which streamlines waste utilisation in earthworks. Our research subject (the policy process) and research setup exemplify the changes in waste policy well. First, our analytical tool, namely 'discursive space', shaped the research object into a comparative form. Second, the research subjects are part of the same policy process, which means there are contextual similarities that validate the comparison between the phases. Policy formulation phases act as openings where the articulatory practice is active during the policy process, and therefore the policy formulation phases are 'under the influence of discourses' that were topical in waste policy discussions at the specific period. This is the manner in which contemporary discourses shape the outcomes of a policy formulation.

The key change between the phases was the emergence of circular economy thinking. It diversified the discursive space in the reform phase compared to the preparation phase, where discursive space was structured by the tension between resource efficiency and precaution. In both phases, deregulatory thinking provided the means (streamlining regulations) of gaining more utility from wastes. The policy processes of preparing and reforming the decree were not plain sailing; different stakeholders had different ideas and interests, and they collided on three key points: (1) the struggle over limitations, (2) facilitation without compromising; and (3) interpretations of the CE.

There are three takeaways from our comparative analysis. First, thinking on sustainability and the CE has gained more ground in waste policy (see also Silva et al., 2016). In particular, the CE became established, as sustainability was discussed through CE thinking in the reform phase and the promotion of the CE was one of objectives of the decree reform (cf. Meadowcroft \& Fiorino, 2017). Moreover, CE thinking has enhanced the idea of upcycling in waste policy, since in the reform phase, plain waste utilisation was not enough; the quality of utilisation also mattered. Second, there were increasing efforts to have wastes categorised as a resource (Kronenberg \& Winkler, 2009), and there was competition for those resources. In the reform phase, this competition translated into a struggle over whether or not waste utilisation in earthworks is a good way to put the CE into practice. This aspect enhances the role of CE thinking in waste policy even further. However, the third takeaway is that the waste producers' take on wastes has remained somewhat 
the same. The key question for them still is what to do with waste. For waste producers, it would be a dream scenario if their wastes were viewed as resources with monetary value. However, in reality wastes bring obligations and costs to the holder. Therefore, procedures that facilitate waste management draw a great deal of interest from waste producers, and they recognise the CE as an argumentative resource to help in their efforts to dispose of their wastes more easily.

While CE thinking attempts to transform wastes into resources (e.g. Silva et al., 2017), the idea of waste being a resource is not new in itself. Waste has always been a resource in waste management practices, whether the practice is landfill, incineration, recycling, or waste utilisation. However, there are differences: first, in CE thinking wastes should produce as much utility as possible and not be perceived of only as manageable objects. Second, if a waste material is categorised as a resource for production processes, it should have as coequal a status as possible with natural virgin resources. However, that coequality is not easy to achieve, as Gregson et al. (2015) have shown. In addition, we should note there are various waste categorisations that are not positive, like waste as a risk, a hazard, or filth (Moore, 2012). These categorisations are the reasons why societies have taken measures to manage waste. Clearly, the emergence of CE thinking has ignited positive developments in waste policy from a sustainability perspective, but the long history of wastes being problematic will not disappear straightaway, and wastes may not be turned into quality resources easily. To conclude, in real-life waste policy situations, the pursuit of the CE adds layers of complexity, competition, and struggle to the discussion of wastes while also enhancing the idea of upcycling.

\section{Acknowledgements}

We wish to thank the interviewees who participated in this research, Jaana Sorvari for her valuable insights on the research topic, and Pekka Jokinen and Ari Jokinen for their constructive feedback during the research process.

\section{Disclosure statement}

The authors report no potential conflicts of interest.

\section{Funding details}

The authors' salaries are paid by their institutions.

\section{References}

Ayres, I., \& Braithwaite, J. (1992). Responsive regulation: Transcending the deregulation debate. New York: Oxford University Press.

Blomsma, F., \& Brennan, G. (2017). The emergence of circular economy: A new framing around prolonging resource productivity. Journal of Industrial Ecology, 21(3), 603-614. doi:10.1111/jiec.12603

Bridgens, B., Powell, M., Farmer, G., Walsh, C., Reed, E., Royapoor, M., Gosling, P., Hall, J. \& Heidrich, O. (2018). Creative upcycling: Reconnecting people, materials and place through making. Journal of Cleaner Production, 189, $145-154$. doi:10.1016/j.jclepro.2018.03.317

Collier, U. (1998). Deregulation in the European Union: Environmental perspectives. Routledge.

de Jesus, A., \& Mendonça, S. (2018). Lost in transition? Drivers and barriers in the eco-innovation road to the circular economy. Ecological Economics, 145, 75-89. doi:10.1016/j.ecolecon.2017.08.001

Di Maria, A., Eyckmans, J., \& Van Acker, K. (2018). Downcycling versus recycling of construction and demolition waste: Combining LCA and LCC to support sustainable policy making. Waste Management, 75, 3-21. doi:10.1016/j.wasman.2018.01.028

Domenech, T., \& Bahn-Walkowiak, B. (2017). Transition towards a resource efficient circular economy in Europe: Policy lessons from the EU and the member states. Ecological Economics, doi:10.1016/j.ecolecon.2017.11.001

Dryzek, J. S. (1997). The politics of the earth: Environmental discourses. Oxford: Oxford University Press.

Elia, V., Gnoni, M. G., \& Tornese, F. (2017). Measuring circular economy strategies through index methods: A critical 
analysis. Journal of Cleaner Production, 142, 2741-2751. doi:10.1016/j.jclepro.2016.10.19

European Commission. (2015) Closing the loop - An EU action plan for the Circular Economy. Retrieved from:

http://eurlex.europa.eu/legal-content/EN/TXT/?qid=1453384154337\&uri=CELEX:52015DC0614

Feindt, P. H., \& Oels, A. (2005). Does discourse matter? Discourse analysis in environmental policy making. Journal of Environmental Policy \& Planning, 7(3), 161-173. doi:10.1080/15239080500339638

Finlex. (2018). Legislative Drafting Process Guide. http://lainvalmistelu.finlex.fi/en/. Accessed: November 7, 2018.

Finnish Transport Agency. (2015). Liikenneviraston ympäristöohjelma 2015-2018. [Environmental programme of Finnish Transport Agency 2015-2018]. (3/2015 Liikenneviraston tomintalinjoja). Retrieved from:

https://julkaisut.liikennevirasto.fi/pdf8/Ito_2015-03_liikenneviraston_ymparistoohjelma_web.pdf

Frosch, R. \& Gallopoulos, N. (1989). Strategies for manufacturing. Scientific American, 261(3), 94-102.

Georgescu-Roegen, N. (1977). The Steady State and Ecological Salvation: A Thermodynamic Analysis. BioScience 27/4, 266-270.

Gregson, N., Crang, M., Fuller, S., \& Holmes, H. (2015). Interrogating the circular economy: the moral economy of resource recovery in the EU. Economy and Society 44/2, 218-243.

Hajer, M. 1995. The Politics of Environmental Discourse -Ecological Modernization and the Policy Process. Clarendon press.

Hajer, M., \& Versteeg, W. (2005). A decade of discourse analysis of environmental politics: Achievements, challenges, perspectives. Journal of Environmental Policy \& Planning 7/3, 175-184.

Hill, J. (2015). The circular economy: from waste to resource stewardship, part I. Proceedings of the Institution of Civil Engineers - Waste and Resource Management 168/1, 3-13.

Howarth, D., \& Stavrakakis, Y. (2000). Introducing Discourse Theory and Political Analysis. In (eds.): Howarth, D., Norval, A. J., \& Stavrakakis, Y. (2000). Discourse theory and political analysis: Identities, hegemonies and social change. Manchester: Manchester University Press.

Howlett, M., \& Giest, S. (2013). Policy-making process. In (eds.): Araral, E. (2013). Routledge Handbook of Public Policy. New York. Routledge. 2013

Hultman, J., \& Corvellec, H. (2012). The European Waste Hierarchy: from the sociomateriality of waste to a politics of consumption. Environment and Planning A, 44(10), 2413-2427.

lacovidou, E., Millward-Hopkins, J., Busch, J., Purnell, P., Velis, C. A., Hahladakis, J. N., Zwirner, O., \& Brown, A. (2017). A pathway to circular economy: Developing a conceptual framework for complex value assessment of resources recovered from waste. Journal of Cleaner Production, 168, 1279-1288. doi:10.1016/j.jclepro.2017.09.002

Jokinen, P., Blicharska, M., Primmer, E., Van Herzele, A., Kopperoinen, L., \& Ratamäki, O. (2018). How does biodiversity conservation argumentation generate effects in policy cycles? Biodiversity and Conservation, 27(7), 1725-1740. doi:10.1007/s10531-016-1216-5

Jurgilevich, A., Birge, T., Kentala-Lehtonen, J., Korhonen-Kurki, K., Pietikäinen, J., Saikku, L., \& Schösler, H. (2016). Transition towards Circular Economy in the Food System. Sustainability, 8(1), 69.

Kaufmann, M., Mees, H., Liefferink, D., \& Crabbé, A. (2016). A game of give and take: The introduction of multi-layer (water) safety in the Netherlands and Flanders. Land Use Policy, 57, 277-286. doi:10.1016/j.landusepol.2016.05.033

Kirchherr, J., Reike, D., \& Hekkert, M. (2017). Conceptualizing the circular economy: An analysis of 114 definitions. Resources, Conservation \& Recycling, 127, 221-232. doi:10.1016/j.resconrec.2017.09.005

Korhonen, J., Honkasalo, A., Seppälä, J. (2018). Circular economy: The concept and its limitations. Ecological Economics, 143, 37-46. doi:10.1016/j.ecolecon.2017.06.041

Korhonen, J., Nuur, C., Feldmann, A., \& Birkie, S. (2018). Circular economy as an essentially contested concept. Journal of Cleaner Production, 175, 544-552. doi:10.1016/j.jclepro.2017.12.111

Kronenberg, J., \& Winkler, R. (2009). Wasted waste: An evolutionary perspective on industrial by-products. Ecological Economics. 68/12, 3026-3033.

Lazarevic, D., \& Valve, H. (2017). Narrating expectations for the circular economy: Towards a common and contested European transition. Energy Research \& Social Science, 31, 60-69. doi:10.1016/j.erss.2017.05.006

Lincoln, Y. S., \& Guba, E. G. (1985). Establishing Trustworthiness. In: Naturalistic inquiry (pp. 289-331). Beverly Hills: Sage.

Lidskog, R., Soneryd, L., Uggla, Y. (2005). Knowledge, power and control-studying environmental regulation in late modernity. Journal of Environmental Policy \& Planning, 7(2), 89-106.

McDonough, W., \& Braungart, M. (2008). Cradle to Cradle. Remaking the Way We Make Things. Vintage.

McDowall, W., Geng, Y., Huang, B., Bartekova, E., Bleischwitz, R., Turkeli, S., Kemp, R., \& Domenech, T. (2017). Circular economy policies in China and Europe. Journal of Industrial Ecology, 21(3), 651-661. doi:10.1111/jiec.12597

Meadowcroft, J. \& Fiorino, D. (2017). Conceptual innovation and Environmental Policy. In James Meadowcroft \& Daniel Fiorino (eds.): Conceptual innovation in Environmental Policy. The MIT Press. 
Mikkola, A. (2013). Valtioneuvoston asetus (591/2006) eräiden jätteiden hyödyntämisestä maarakentamisessa ilmoitusmenettelyn toimivuus ja sen parantaminen (Master's thesis). [Government Decree (591/2006) on recovery of certain wastes in earth construction - utility and improving of the notification procedure]. Aalto University, School of Engineering.

Milios, L. (2018). Advancing to a circular economy: Three essential ingredients for a comprehensive policy mix. Sustainability Science, 13(3), 861-878. doi:10.1007/s11625-017-0502-9

Ministry of Finance. (2012). Maa-ainesvero. Selvitys maa-ainesveron käyttöönoton mahdollisuuksista ja tarkoituksenmukaisuudesta (policy memoranda). [An exploration of the possibilities and appropriateness of the introduction of sand, gravel and rock extraction tax]. Retrived from: vm.fi/dms-portlet/document/0/397878

Ministry of the Environment. (2006). Ehdotus valtioneuvoston asetukseksi eräiden jätteiden hyödyntämisestä maarakentamisessa (Memoranda). [Proposal for Government Decree on the recovery of certain waste in earth construction]

Ministry of the Environment. (2016). Ehdotus valtioneuvoston asetukseksi eräiden jätteiden hyödyntämisestä maarakentamisessa. (Draft Memoranda). [Proposal for Government Decree on the recovery of certain waste in earth construction]

Ministry of the Environment. (2017). Ehdotus valtioneuvoston asetukseksi eräiden jätteiden hyödyntämisestä maarakentamisessa. (Memoranda). [Proposal for Government Decree on the recovery of certain waste in earth construction]

Moore, S. (2012). Garbage matters: Concepts in new geographies of waste. Progress in Human Geography 36(6), 780799.

Nylén, E-J. (2019). Can abstract ideas generate change? The case of the circular economy. In (eds.): Kangas, A., Kujala, J., Heikkinen, A., Lönnqvist, A., Laihonen, H. \& Bethwaite, J. (2019). Leading change in a complex world: Transdisciplinary perspectives. Tampere University Press.

Paul, K. (2009). Discourse analysis: an exploration of methodological issues and a call for methodological courage in the field of policy analysis. Critical Policy Studies 3/2, 240-253.

Pol, V. G. (2010). Upcycling: Converting waste plastics into paramagnetic, conducting, solid, pure carbon microspheres. Environmental Science \& Technology, 44(12), 4753-4759. doi:10.1021/es100243u

Reno, J. (2009). Your trash is someone's treasure: The politics of value at a Michigan landfill. Journal of Material Culture, 14(1), 29-46. doi:10.1177/1359183508100007

Schmidt, V. A. (2017). Theorizing ideas and discourse in political science: Intersubjectivity, neo-institutionalisms, and the power of ideas. Critical Review, 29(2), 248-263. doi:10.1080/08913811.2017.1366665

Schmidt, V. A. (2008). Discursive institutionalism: The explanatory power of ideas and discourse. Annual Review of Political Science, 11(1), 303-326. doi:10.1146/annurev.polisci.11.060606.135342

Schwartz-Shea, P. (2015). Judging Quality. Evaluative Criteria and Epistemic Communities. In: Schwartz-Shea, P., \& Yakow, D. (Ed.) Interpretation and Method: Empirical Research Methods and the Interpretive Turn (pp. 89-115). Abingdon, Oxon: Routledge.

Silva, A., Rosano, M., Stocker, L., \& Gorissen, L. (2017). From waste to sustainable materials management: Three case studies of the transition journey. Waste Management, 61, 547-557. doi:10.1016/j.wasman.2016.11.038

Silva, A., Stocker, L., Mercieca, P., \& Rosano, M. (2016). The role of policy labels, keywords and framing in transitioning waste policy. Journal of Cleaner Production, 115, 224-237.

Sitra. (2016). Leading the cycle - Finnish road map to a circular economy 2016-2025. Sitran studies 121. Retrived from: https://media.sitra.fi/2017/02/24032659/Selvityksia121.pdf

Sitra. (2015). The opportunities of a circular economy for Finland. Sitran studies 100. Ewreko, Helsinki 2014. Retrived from: https://media.sitra.fi/2017/02/28142449/Selvityksia100.pdf

Sormunen, L. A. (2017). Recovered Municipal Solid Waste Incineration Bottom Ash: Aggregate-Like Products for Civil Engineering Structures. (Tampere University of Technology. Publication; Vol. 1503). Tampere University of Technology

Sorvari, J. (2008). Developing environmental legislation to promote recycling of industrial by-products - an endless story? Waste Management, 28(3), 489-501.

Su, B., Heshmati, A., Geng, Y., \& Yu, X. (2013). A review of the circular economy in china: Moving from rhetoric to implementation. Journal of Cleaner Production, 42, 215-227. doi:10.1016/j.jclepro.2012.11.020

Thomas, G., \& Myers, K. (2017). The anatomy of the case study. SAGE Publications Ltd. http://dx.doi.org/10.4135/9781473920156

Timmermans, A., \& Scholten, P. (2006). The political flow of wisdom: science institutions as policy venues in The Netherlands, Journal of European Public Policy, 13:7, 1104-1118. DOI: 10.1080/13501760600924209

Turnpenny, j., Jordan, A., Benson, D., \& Rayner, T. (2015). The tools of policy formulation: an Introduction. In (eds.): 
Jordan, A., \& Turnpenny, J. (2015). The tools of policy formulation: Actors, capacities, venues and effects. Cheltenham: Edward Elgar Publishing. doi:10.4337/9781783477043

VTT. (2006). Tausta-aineistoa "Valtioneuvoston asetuksen eräiden jätteiden hyödyntämisestä maarakentamisessa" valmistelua varten. [Background data for the drafting of 'Government Decree on the recovery of certain waste in earth construction'].

Wilts, H., von Gries, N., \& Bahn-Walkowiak, B. (2016). From waste management to resource Efficiency-The need for policy mixes. Sustainability, 8(7), 622. doi:10.3390/su8070622

Government Decree 591/2006. Valtioneuvoston asetus eräiden jätteiden hyödyntämisestä maarakentamisessa. [Government Decree on the recovery of certain waste in earth construction]. Retrieved from: http://www.finlex.fi/fi/laki/alkup/2006/20060591

Government Decree 403/2009. Valtioneuvoston asetus eräiden jätteiden hyödyntämisestä maarakentamisessa annetun valtioneuvoston asetuksen liitteiden muuttamisesta. [Amendments to the Annexes of Government Decree on the recovery of certain waste in earth construction]. Retrieved from: https://www.finlex.fi/fi/laki/alkup/2009/20090403

Government Decree 843/2017. Valtioneuvoston asetus eräiden jätteiden hyödyntämisestä maarakentamisessa.

[Government Decree on the recovery of certain waste in earth construction]. Retrieved from: https://www.finlex.fi/fi/laki/alkup/2017/20170843

Waste law 646/2011. Jätelaki. [Waste Law]. Retrieved from: https://www.finlex.fi/fi/laki/alkup/2017/20170843

Waste Law 1072/93. Jätelaki. [Waste Law]. Retrieved from: https://www.finlex.fi/fi/laki/ajantasa/kumotut/1993/ 